\title{
Evaluation of neutrophil to lymphocyte ratio, platelet to lymphocyte ratio, and lymphocyte to monocyte ratio in patients with cellulitis
}

\author{
Devin Ince ${ }^{1}$ \\ (iD) Ertuğrul Güçlü \\ (D) Mehmet Ali Sungur ${ }^{3}$ \\ (iD) Oğuz Karabay²
}

\begin{abstract}
1. Department of Infectious Diseases and Clinical Microbiology, Duzce University Faculty of Medicine, Duzce, Turkey 2. Sakarya University Medical Faculty Teaching and Research Hospital Infectious Diseases and Clinical Microbiology Department, Sakarya, Turkey 3. Department of Biostatistics, Duzce University Faculty of Medicine, Duzce, Turkey
\end{abstract}

\section{SUMMARY}

OBJECTIVE: Cellulite infection is a non-necrotizing inflammation of the skin and subcutaneous tissue and is one of the most common reasons for admission to hospital. This retrospective study aimed to investigate the Neutrophil to Lymphocyte Ratio (NLR), Platelet to Lymphocyte Ratio (PLR), and Lymphocyte to Monocyte Ratio (LMR) in patients with cellulitis.

METHODS: In our study, we retrospectively analyzed 96 patients with cellulitis and 98 age- and sex-matched healthy controls. The study and control groups were compared regarding NLR, PLR, and LMR.

RESULTS: The PLR and NLR of the cellulitis group were significantly higher than those of the control group $(p<0.001)$. When patients with cellulitis were divided into two groups, i.e., $\geq 65$ years and $<65$ years, a statistically significant difference was noted in the NLR and $L M R$ values $(p<0.05)$. In the ROC curve analysis, NLR had the highest discriminative power in distinguishing between cellulitis and healthy controls ( $A \cup C=0.950,95 \% \mathrm{Cl}$ : 0.920-0.979, $p<0.001 ; 91.6 \%$ sensitivity and 89.8\% specificity).

CONCLUSION: NLR was significantly higher in differentiating cellulite and in patients older than 65 years. Larger, prospective studies are required to determine its usefulness in assessing differential diagnosis and prognosis in cellulitis patients.

KEYWORDS: Cellulitis. Lymphocytes. Neutrophils. Blood platelets. Monocytes. Diagnosis.

\section{INTRODUCTION}

Cellulitis is a non-necrotizing inflammation of the skin and subcutaneous tissue that is caused by the Staphylococcus or Streptococcus bacterium'. It is estimated that 2.3 million people visit the emergency room annually due to cellulitis ${ }^{2}$. Cellulitis occurs most frequently in the lower extremities and usually unilaterally. Several risk factors such as lymphedema, venous insufficiency, traumatic wounds, leg ulcers, and intertrigo are associated with cellulitis ${ }^{3,4}$. Clinically, erythema, edema, temperature, and sensitivity develop in the patient's skin ${ }^{5}$. There is no definitive or reliable diagnostic method for cellulitis, which is one 
of the most frequently occurring infectious diseases requiring hospitalization. The spectrum of the disease can range from localized erythema in a systemically well patient to rapidly spreading erythema and fulminant sepsis occurring concurrently with necrotizing fasciitis ${ }^{6}$. Clinical findings based on anamnesis and physical examination should be evaluated together for the diagnosis. Routine biochemical and hematological blood tests and blood cultures are not specific for the diagnosis of cellulitis'. Recently, it has been pointed out that the changes in peripheral blood leukocyte ratios are a simple, rapid, and novel, promising inflammation parameter for several diseases ${ }^{7-9}$. Some of these markers are Neutrophil/Lymphocyte Ratio (NLR), Platelet/Lymphocyte Ratio (PLR), and Lymphocyte/Monocyte Ratio (LMR).

NLR, PLR, and LMR values have been suggested to be useful in differentiating between infections and predicting prognosis ${ }^{10,11}$. The ready availability and low cost of such parameters would make them particularly helpful in low- and middle-income countries. Hemogram parameters have been used in the viral-bacterial differentiation of infections. In a study with cases in which patients in the hospital had fever were examined retrospectively, it was found that NLR was higher in patients with fever due to bacterial infections than those with viral infection ${ }^{8}$.

To the best of our knowledge, there is no study investigating the peripheral blood leukocyte ratios in cellulitis in the literature. Therefore, in the present study, we aimed to evaluate the relationship between the use of hemogram parameters as diagnostic biomarkers and age and the duration of hospital stay in patients with cellulitis.

\section{METHODS}

\section{Study population and design}

We enrolled 96 patients who were diagnosed with cellulitis at the Department of Infectious Disease of Duzce University Medicine Faculty Hospital and Sakarya University Medical Faculty Teaching and Research Hospital, from January 2017 to March 2019. Patients' medical records were retrospectively reviewed. The control group included 98 age- and sex-matched healthy subjects. Age, sex, involved site(s), infectious route, systemic manifestations, and the duration of hospital stay were evaluated. Patients' demographic characteristics, age, sex, clinical findings, involved site(s), the duration of hospital stay, blood values (white blood cell [WBC], neutrophil count, lymphocyte count, monocyte count, and platelet count [PLT]) were recorded in forms. NLR, PLR, and LMR were calculated as the ratio of neutrophils to lymphocytes, platelets to lymphocytes, and monocytes to lymphocytes, respectively. Venous blood samples were obtained simultaneously to determine the peripheral blood leukocyte ratios on the first day after admission before receiving antimicrobial therapy.

\section{Blood sample analyses}

Venous blood samples were collected in sterile standard tubes containing ethylenediaminetetraacetic acid as an anticoagulant. Complete blood count parameters were measured using the Abbott CELL-DYN 3700 automatic analyzer.

\section{Statistical Analysis}

The distribution of the data was examined using the Kruskal-Wallis test. Independent samples t-test was used for continuous variables showing normal distribution, and the Mann-Whitney U test was used for continuous variables not showing normal distribution. Cut-off values were calculated using receiver operating characteristic (ROC) curve analysis for parameters that differ significantly in Cellulitis and control group comparisons. The relationships between categorical variables were examined using Pearson chi-square or Fisher-Exact tests. Statistical analysis was performed with SPSS v.22 package program, and the significance level was considered as 0.05 .

\section{RESULTS}

Our study included 96 patients with cellulitis and 98 healthy, age- and sex-matched control subjects. The male/female ratio of patients with cellulitis was 39/57, while it was 35/63 for the control group. The mean age of the patients with cellulitis was $66.01 \pm 12.13$ years, and the mean age of the control group was $63.66 \pm 9.91$. No statistically significant difference was noted between the groups for age and sex; $92.7 \%$ of the patients had cellulitis in the lower extremities, $5.2 \%$ had cellulitis in the upper extremities, and 2.1\% had cellulitis in the body. The WBC, PLR, and NLR of the cellulitis group were significantly higher than those of the control group $(\mathrm{p}<0.001)$. In the cellulitis group, the Hb, PLT, and LMR were lower compared with those in the control group $(p<0.001)$. Laboratory 
data of the cellulitis and control groups are summarized in Table 1.

The data regarding the evaluation of the cellulitis group by age are presented in Table 2 . Accordingly, when patients with cellulitis were divided into two groups as $\geq 65$ years and $<65$ years, a statistically significant difference was noted among the WBC, NLR, and LMR values $(p<0.05)$, while a difference was noted among the Hb levels, PLT, and PLR ( $p>0.05)$. No significant relationship was noted between the duration of hospital stay of patients with cellulitis and their peripheral blood leukocyte ratios ( $p>0.05)$.

In the ROC curve analysis, areas under the curve (AUC) of WBC, Hb, PLT, PLR, NLR, and LMR were 0.919, 0.672, 0.645, 0.691, 0.950, and 0.814, respectively. Of these parameters, NLR showed the highest discriminative power in distinguishing between cellulitis and healthy controls (AUC $=0.950,95 \%$ CI: 0.920-0.979, $\mathrm{p}<0.001 ; 91.6 \%$ sensitivity and $89.8 \%$ specificity). The comparison of the ROC curves of parameters is shown in Fig. 1.

\section{DISCUSSION}

We know that laboratory parameters and clinical symptoms are unspecific in cellulitis. Presently, no appropriate case definition and definitive diagnostic criteria exist for cellulitis ${ }^{12}$. To the best of our knowledge, this is the first study to investigate the peripheral blood leukocyte ratios in cellulitis infections. The primary findings of our study were that WBC, PLR, and NLR levels were significantly higher in cellulitis than in the control group. In addition, when we divided the patients by age ( $<65$ and $\geq 65$ years), a significant difference was noted in the NLR and LMR values between the groups.

An increase in the NLR and a decrease in the LMR are considered indicators of systemic inflammation. Several studies have indicated that NLR, PLR, and LMR may predict systemic inflammation, and these markers may be useful in many disease ${ }^{13-15}$. Horne et al. ${ }^{16}$ reported that NLR is more effective than leukocyte levels in predicting inflammation. In a study conducted by Kartal et al. ${ }^{17}$, a significant difference was found between community-acquired pneumonia and control groups in terms of NLR and PLR values. Similar to other studies, in our study, patients with cellulitis had higher levels of PLR and NLR than those in the control group.

Studies investigating the role of peripheral blood leukocyte rates in predicting complications and prognosis in various diseases reported that PLR and NLR

\section{TABLE 1. DEMOGRAPHIC AND LABORATORY CHARACTERISTICS FOR THE TWO GROUPS.}

\begin{tabular}{l|l|l|l}
\multicolumn{2}{c}{ Cellulitis group $(n=96)$} & Healtyh control group $(n=98)$ & P value \\
$\begin{array}{l}\text { Gender }[n(\%)] \\
\text { Female } \\
\text { Male }\end{array}$ & $\begin{array}{l}5(59.4 \%) \\
39(40.6 \%)\end{array}$ & $\begin{array}{l}63(64.3 \%) \\
35(35.7 \%)\end{array}$ & 0.481 \\
\hline Age & $66.01 \pm 12.13$ & $63.66 \pm 9.91$ & 0.141 \\
\hline WBC $\left(10^{9} / \mathrm{L}\right)$ & $14100(1000-35800)$ & $6445(4000-72100)$ & $<0.001$ \\
\hline $\mathrm{Hb}(\mathrm{g} / \mathrm{dl})$ & $12.36 \pm 1.67$ & $13.32 \pm 1.19$ & $<0.001$ \\
\hline Plt $\left(10^{3} / \mathrm{mm}^{3}\right)$ & 204500 & 245500 & 0.001 \\
\hline Median $\left(\mathrm{min}^{-m a x}\right)$ & $(67000-438000)$ & $(75000-409000)$ & $<0.001$ \\
\hline PLR & $160.68(41.22-710.00)$ & $115.39(0.15-307.50)$ & $<0.001$ \\
\hline NLR & $8.65(1.70-34.36)$ & $1.76(0.71-17.93)$ & $<0.001$ \\
\hline LMR & $2.15(0.37-12.00)$ & $4.51(1.14-10.91)$ & \\
\hline
\end{tabular}

WBC: White blood cell count; Hb: hemoglobin; PIt: platelet count; PLR: platelet-to lymphocyte ratio; NLR; neutrophil-to-lymphocyte ratio; LMR: lymphocyte-to-monocyte ratio.

TABLE 2. COMPARISON OF HEMOGRAM PARAMETERS OF CELLULITE GROUP ACCORDING TO AGE.

\begin{tabular}{l|l|l|l}
\multicolumn{1}{l}{ Age $<65(\mathrm{n}=38)$} & \multicolumn{1}{l}{ Age $\geq 65(\mathrm{n}=58)$} & \\
\hline WBC $\left(10^{9} / \mathrm{L}\right)$ & $12050(3900-26300)$ & $14600(1000-35800)$ & 0.026 \\
\hline $\mathrm{Hb}(\mathrm{g} / \mathrm{dl})$ & $12.70 \pm 1.74$ & $12.14 \pm 1.60$ & 0.104 \\
\hline $\begin{array}{l}\text { Plt }\left(10^{3} / \mathrm{mm}^{3}\right) \\
\text { Median }(\mathrm{min}-\mathrm{max})\end{array}$ & $215000(67000-413000)$ & $203500(110000-438000)$ & 0.449 \\
\hline PLR & $154.96(60.45-678.00)$ & $178.89(41.22-710.00)$ & 0.438 \\
\hline NLR & $7.04(2.06-25.30)$ & $10.06(1.70-34.36)$ & 0.032 \\
\hline LMR & $2.58(0.67-12.00)$ & $1.85(0.37-7.20)$ & 0.032 \\
\hline
\end{tabular}


FIGURE 1. RECEIVER OPERATING CHARACTERISTIC (ROC) CURVES OF THE HEMOGRAM PARAMETERS FOR DIFFERENTIATING CELLULITIS PATIENTS FROM HEALTHY ONES.

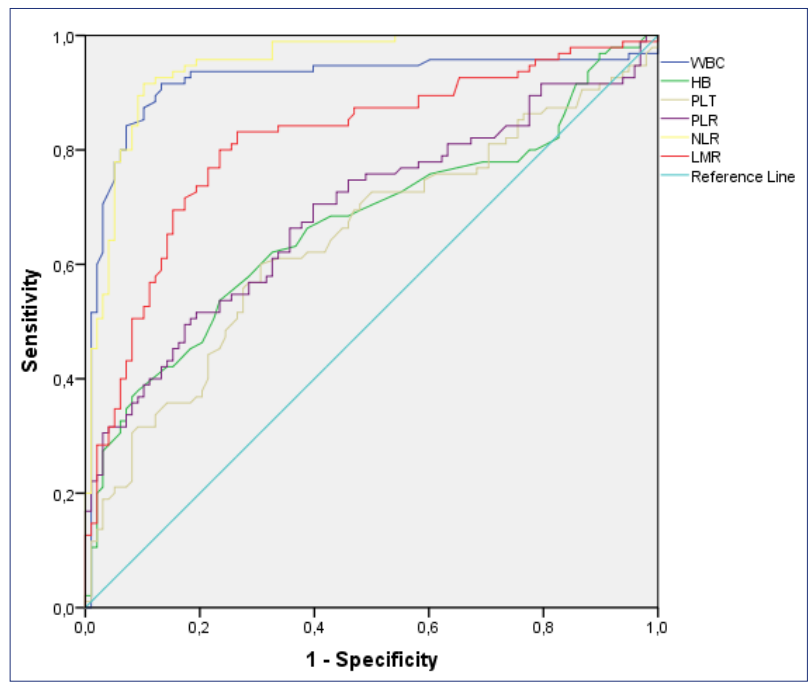

rates can be used as prognostic markers with diagnoses. For example, two different studies revealed higher NLR rates in patients requiring amputation in diabetic foot infections and in those with osteoarticular involvement in brucella infection ${ }^{14,18}$. Yapici et al. ${ }^{19}$ showed in their study that the NLR values of patients who had diabetic foot infection with concurrent osteomyelitis were significantly higher than those without osteomyelitis $(p=0.004)$. The treatment period for cellulitis infections is recommended as 5-10 days. Longer treatment may be required in cases of clinical unresponsiveness or in cases of lower extremity edema and obesity ${ }^{20}$. In the present study, no significant relationship was noted between the requirement for prolonged hospitalization ( $\geq 10$ days) and PLR, NLR, and LMR levels in patients with cellulitis.

There are few studies evaluating the peripheral blood leukocyte rates' relationship with disease and age. In a prospective study, it was reported that NLR may reflect systemic inflammatory processes in Alzheimer's disease, and that age is a dominant variable that should be considered ${ }^{21}$. In a study conducted by Cataudella et al..$^{22}$, patients with community-acquired pneumonia over 65 years of age were evaluated. In this study, it was found that NLR was more of a prognostic marker for the diagnosis and mortality of patients over 65 years of age in community-acquired pneumonia. In our study, we divided patients with cellulitis into groups over and under 65 years of age and evaluated whether there is a relationship between age and peripheral blood leukocyte rates. No difference was noted in PLR values between age groups, whereas NLR was significantly lower in the group of patients under 65 years $(p=0.032)$ and LMR was significantly higher in the group of patients over 65 years $(p=0.032)$. Further studies are required to establish a relationship between age and peripheral blood leukocyte ratios.

This study has some limitations. First, it was retrospectively conducted and the sample size is relatively small. Second, patients were compared using only hemogram parameters and rates. Other inflammatory biomarkers were not evaluated. Third, the complete blood count parameters of patients with cellulitis were compared at the beginning of treatment. Changes in parameters after treatment were not examined.

\section{CONCLUSION}

In conclusion, peripheral blood leukocyte rates are fairly simple, inexpensive, and easy for evaluating new inflammatory biomarkers. We found that the PLR, NLR, and LMR values were significantly different in the patients with cellulitis compared with the healthy control group. Our study is the first in the literature showing peripheral blood leukocyte rates in patients with cellulitis. We believe that the use of these parameters together with clinical diagnosis in the planning for further studies will help in differential diagnosis and prognosis.

\section{Source of support}

None.

\section{Conflict of interest}

None.

Approval was obtained from Sakarya University and Düzce University Medical Faculty Ethics Committee in 2019/244.

\section{Author's Contribution}

Nevin Ince: study design, writing, and data collection; Ertuğrul Güçlü: data collection; Mehmet Ali Sungur: statistics; Oğuz Karabay: study design and writing. 


\section{RESUMO}

OBJETIVO: A celulite infecciosa é uma inflamação não necrotizante da pele e do tecido subcutâneo e uma das causas mais comuns para internação. O objetivo deste estudo retrospectivo foi investigar as relações Neutrófilo/Linfócito (RNL), Plaqueta/Linfócito (RPL) e Linfócito/Monócito (RLM) em pacientes com celulite.

MÉTODOs: Nós analisamos, retrospectivamente, 96 pacientes com celulite e 98 controles saudáveis equivalentes em sexo e idade. Os grupos foram comparados quanto a RNL, RPL e RLM.

RESULTADOS: Os valores de RPL e RNL do grupo com celulite foram significativamente mais elevados do que os do grupo de controle $(p<0,001)$. Após dividir os pacientes com celulite em dois grupos, $\geq 65$ anos e $<65$ anos, uma diferença estatisticamente significativa foi observada nos valores de RNL e RLM ( $p<0,05)$. Na análise da curva ROC, a RNL apresentou o maior poder de discriminação para distinguir entre pacientes com celulite e controles saudáveis ( $A \cup C=0,950,95 \%$ Cl: 0,920 - 0,979; $p<0,001 ; 91,6 \%$ de sensibilidade e $89,8 \%$ de especificidade).

CONCLUSÃO: O valor de RNL foi significativamente maior para a diferenciação de pacientes com celulite e pacientes com mais de 65 anos. Estudos prospectivos maiores são necessários para determinar a sua utilidade na avaliação de diagnósticos diferenciais e prognósticos em pacientes com celulite.

PALAVRAS-ChaVe: Celulite. Linfócitos. Neutrófilos. Plaquetas. Monócitos. Diagnóstico.

\section{REFERENCES}

1. Raff AB, Kroshinsky D. Cellulitis: a review. JAMA. 2016;316(3):325-37.

2. Talan DA, Salhi BA, Moran GJ, Mower WR, Hsieh YH, Krishnadasan A et al. Factors associated with decision to hospitalize emergency department patients with skin and soft tissue infection. West J Emerg Med. 2015;16(1):89-97.

3. Pitché $P$, Diatta $B$, Faye $O$, Diané BF, Sangaré $A$, Niamba $P$, et al. Risk factors associated with leg erysipelas (cellulitis) in sub-Saharan Africa: a multicentre case-control study. Ann Dermatol Venereol. 2015;142(11):633-8.

4. Roujeau JC, Sigurgeirsson B, Korting HC, Kerl H, Paul C. Chronic dermatomycoses of the foot as risk factors for acute bacterial cellulitis of the leg: a case-control study. Dermatology. 2004;209(4):301-7.

5. Cranendonk DR, Lavrijsen APM, Prins JM, Wiersinga WJ. Cellulitis: current insights into pathophysiology and clinical management. Neth | Med. 2017;75(9):366-78.

6. Sullivan T, Barra E. Diagnosis and management of cellulitis. Clin Med. 2018;18(2):160-3.

7. Sen V, Bozkurt IH, Aydogdu O, Yonguc T, Yarimoglu S, Sen P, et al. Significance of preoperative neutrophil-lymphocyte count ratio on predicting postoperative sepsis after percutaneous nephrolithotomy. Kaohsiung | Med Sci. 2016;32(10):507-13.

8. Naess A, Nilssen SS, Mo R, Eide GE, Sjursen H. Role of neutrophil to lymphocyte and monocyte to lymphocyte ratios in the diagnosis of bacterial infection in patients with fever. Infection. 2017;45(3):299-307.

9. Karagoz I, Yoldas H. Platelet to lymphocyte and neutrophil to lymphocyte ratios as strong predictors of mortality in intensive care population. Rev Assoc Med Bras (1992). 2019;65(5):633-6.

10. Loonen AJ, de Jager CP, Tosserams J, Kusters R, Hilbink M, Wever PC, et al. Biomarkers and molecular analysis to improve bloodstream infection diagnostics in an emergency care unit. PLoS One. 2014;9(1):e87315.

11. Terradas R, Grau S, Blanch J, Riu M, Saballs P, Castells X, et al. Eosinophil count and neutrophil-lymphocyte count ratio as prognostic markers in patients with bacteremia: a retrospective cohort study. PLoS One. 2012;7(8):e42860.

12. Patel M, Lee SI, Akyea RK, Grindlay D, Francis N, Levell NJ, et al. A systematic review showing the lack of diagnostic criteria and tools developed for lower-limb cellulitis. Br J Dermatol. 2019;181(6):1156-65.
13. Togan $T$, Narci $H$, Turan $H$, Ciftci $O$, Kursun E, Arslan $H$. The impact of acute brucellosis on mean platelet volume and red blood cell distribution. Jundishapur | Microbiol. 2015;8(2):e20039.

14. Balın ŞÖ, Tartar AS, Akbulut A. The predictive role of haematological parameters in the diagnosis of osteoarticular brucellosis. Afri Health Sci. 2018;18(4):988-94.

15. Zhang H, Xia H, Zhang L, Zhang B, Yue D, Wang C. Clinical significance of preoperative neutrophil-lymphocyte vs platelet-lymphocyte ratio in primary operable patients with non-small cell lung cancer. Am J Surg. 2015;210(3):526-35.

16. Horne BD, Anderson JL, John JM, Weaver A, Bair TL, Jensen KR, et al. Which white blood cell subtypes predict increased cardiovascular risk? | Am Coll Cardiol. 2005;45(10):1638-43.

17. Kartal O, Kartal AT. Value of neutrophil to lymphocyte and platelet to lymphocyte ratios in pneumonia. Bratisl Lek Listy. 2017;118(9):513-6.

18. Demirdal T, Sen P. The significance of neutrophil-lymphocyte ratio, platelet-lymphocyte ratio and lymphocyte-monocyte ratio in predicting peripheral arterial disease, peripheral neuropathy, osteomyelitis and amputation in diabetic foot infection. Diabetes Res Clin Pract. 2018;144:118-25.

19. Yapıcı O, Berk H, Öztoprak N, Seyman D, Tahmaz A, Merdin A. Can ratio of neutrophil-to-lymphocyte count and erythrocyte sedimentation rate in diabetic foot infecti predict osteomyelitis and/or amputation? Hematol Rep. 2017;9(1):6981.

20. Stevens DL, Bisno AL, Chambers HF, Dellinger EP, Goldstein El, Gorbach S, et al; Infectious Diseases Society of America. Practice guidelines for the diagnosis and management of skin and soft tissue infections: 2014 update by the Infectious Diseases Society of America. Clin Infect Dis. 2014;59(2):e10-52.

21. Rembach A, Watt AD, Wilson WJ, Rainey-Smith S, Ellis KA, Rowe CC, et al; AIBL Research Group. An increased neutrophil-lymphocyte ratio in Alzheimer's disease is a function of age and is weakly correlated with neocortical amyloid accumulation. J Neuroimmunol. 2014;273(1-2):65-71.

22. Cataudella E, Giraffa CM, Di Marca S, Pulvirenti A, Alaimo S, Pisano M, et al. Neutrophil-to-lymphocyte ratio: an emerging marker predicting prognosis in elderly adults with community-acquired pneumonia. I Am Geriatr Soc. 2017;65(8):1796-801. 